\title{
To the Issue of Organization of Transport Service of Limited Mobility People
}

\author{
Norair Bludyan ${ }^{1 *}$ \\ ${ }^{1}$ Moscow Automobile and Road Construction State Technical University (MADI), 64 Leningradsky \\ prosp., 125319, Moscow, Russia
}

\begin{abstract}
This article represents the analysis results of normative legal regulation in the transport services field for people with limited mobility (LMP) and assessment methods of transport services quality provided by public transport for the same social group. The main conclusions of the significance examination of quality parameters are given below. The essential problems of transport accessibility provision were defined by materials of sociological polls.
\end{abstract}

\section{Introduction}

Meeting the persons' with disabilities and other LMP's needs is one of the most important tasks of transport infrastructure planning and state regulation of transport activities.

The Russian Federation signed the UN Convention on the Rights of Persons with Disabilities in 2008 and ratified it in 2012. The main principle of the convention is complete involvement of disabled people in society by providing them with transport accessibility, information, communications and other facilities and services on a basis to be equal with other groups of the population. In 1992, the President of the Russian Federation adopted the Decree "On measures to create an accessible environment for the persons with disabilities".

In 1995, the Federal Act "Social Protection of Persons with Disabilities in the Russian Federation", which lays down the basic provisions necessary for the creation of an environment accessible for the persons with disabilities was accept [1].

The Federal Act of 1 December 2014, No. 419-FA [2] has entered into force on 1 January 2016. Regarding transport service of the passengers, it will make corresponding changes to the "Charter of road transport and urban ground electric transport» [3].

In order to integrate persons with disabilities into society and improve their living standards was developed by the state program "Accessible environment" for 2011 - 2020 [4].

The main provisions of the program require the evaluation and implementation of activities to ensure the availability of priority facilities and services for LMP.

In accordance with the State program indicator - "the proportion available of priority objects of social, transport, engineering infrastructure in total of priority objects to persons with disabilities and other LMP" must reach $68.2 \%$ by 2020 .

* Corresponding author: $\underline{\text { Np-tama@mail.ru }}$ 
In order to implement measures to improve the accessibility of infrastructure facilities for persons with disabilities, in territorial subjects of the Russian Federation was developed "The indicative program of the territorial subject of the Russian Federation of objects and services in priority spheres of life of persons with disabilities and other LMP" [5].The program contains three target indicators of transport services for LMP.

Recommendations for determining the actual level of quality of transport service for LMP can be attributed to the disposal of the Ministry of transport of Russia from January 31, 2017. no ON-19-R [6].The document defines the availability indicators of bus stations, rolling stock and price availability. However, there are no availability indicators for different group of LMP. Also, there are no criteria for pedestrian accessibility of stopping points for different group of LMP. In addition, there is no indicator in the standard that takes into account the information provided to passengers before the trip, the importance of each indicator for each LMP group etc.

The order of the Ministry of Transport of the Russian Federation established Requirements for carriers to meet the needs of the LMP [7]

In Moscow territory, the Moscow City Law of January 17, 2001, No. 3 is in effect [8].According to this Law all objects of transport infrastructure should be equipped with special devices for access and use of LMP.

This Act does not permit the purchase of the rolling stock for Moscow not adapted for LMP.

The special Moscow government Decree has provided further adaptation of city infrastructure for needs of LMP, defined the responsibilities of executive power heads in Moscow [9].

Moscow city construction norms "Norms and rules of design of complex improvement in the Moscow "determine conditions of design improvement given the unhindered movement of LMP [10].

Code of Regulations "Urban Environment. Design rules for LMP" defines the basic elements and principles of building a barrier-free environment.

Requirements to transport and pedestrian communications, to parking, to transport hubs are approved in the sphere of transport infrastructure.

Russian State standard GOST 51090-97 [11] established the requirements for the construction and equipment of rolling stock to a subsidiary landing devices (lifting devices, ramps). Specific standards set requirements for each type of public passenger transport separately.

The analysis of legal regulation problems of transport by road of certain population groups made in [12]. Since 2011, Moscow has been carrying out complex works on the adaptation of land transport to the requirements of LMP, purchased new rolling stock that meets all the necessary requirements.

The entire buses fleet of SUE "Mosgortrans" and commercial carriers was adapted for carriage LMP. According to SUE "Mosgortrans" data, over $65 \%$ of trolleybuses have a low-floor level. Currently operates 60 trams equipped for LMP transportation in 2017 it is planned to purchase another 300 low-floor trams.

SUE "Mosgortrans" makes social transportations by 150 units of rolling stock, equipped with special elevators or ramps.

\section{Assessment methods of transport services quality for LMP}

There is a range of Russian scientists' researches dedicated the assessment problems of transport services quality for LMP.

The author of dissertation [13] suggested an accessibility criterion of four elements of movement logistic chain for $i$-type LMP. The accessibility is determined by the three 
categories. These categories are the following: available $(+)$, partially available $(+/-)$, not available (-). The categories are measured as a percentage (\%).

An assessment model of public transport routes' accessibility for LMP is explored in the article [14].

Due to the lack of a methodology for assessing the transport and pedestrian accessibility factor of a bus (or other) stop (SP) and their significance the applying of this model is quite complicated. The evaluation of the trip time (depends on interval of low-floor and wheelchair accessible transport units' movement), level of information provision during the planning process and during the trip and the comfort level of the trip are required for an integrated assessment of LMP's transport service.

A four-level scale for SP's accessibility determination is proposed by the author of the paper [15] according to his accessibility methodology. The scale is the following:

1. Perfect accessibility of the SP $(3,7-4,0)$;

2. Good accessibility of the SP $(3,4-3,7)$;

3. Satisfactory accessibility of the SP $(2,5-3,4)$;

4. Unsatisfactory accessibility of the SP $(0-2,5)$.

In order to evaluate the criteria the method of expert assessments is proposed to use by the authors. The SP's accessibility assessment methodology is similar to public transport routes assessment methodology, reviewed in [14]. The difference is that in this methodology the factor "veto" was introduced as well as an additional factor of availability of low-floor and wheelchair accessible transport units on the route. However criteria for additional factor evaluation were not determined.

An assessment methodology of State Program "Accessible Environment" activities implementation is presented in article [16]. However, this methodology does not allow giving an integrated assessment of the LMP's transport service taking into account the significance of each quality parameter.

The system analysis of the performed researches allows us to draw a conclusion about the absence of an integrated approach to assessing the quality parameters of transport services taking into account importance for different categories of LMP.

According to research $[12,16,17]$ the definition of the main criteria, systematization and the determination of their importance are primary steps on the way to the transport service quality assessment.

The decision to reject using cost indicator, reviewed in [18] is based on the fact, that majority of LMP are persons with disabilities and senior persons (75\%, according to the materials of the Center for passengers mobility of SUE "Moscow Metropolitan"), who use the right of preferential trip on public transport.

\section{The results of sociological poll of LMP in Moscow}

The results of sociological poll of LMP in Moscow indicated importance of transport service quality indicators.

1. Movement reliability (trip time, taking into account the accessibility of road network facilities and transport infrastructure for LMP) $-42,3 \%$.

2. Movement regularity (movement frequency of the LMP's adapted transport unities) $10,2 \%$.

3. Safety (probability of failure-free operation of the LMP's adapted transport unities) $9,1 \%$.

4. Comfort (trip comfort for LMP) - 16,8\%.

5. Information service indicator (level of information support for LMP) $-21.6 \%$.

The accessibility of road network indicators on the way to SP and their significance were established for each category of LMP. 
I For people with musculoskeletal disorders (including wheelchairs users):

- The presence of low side stone at pedestrian crossings - 50,4\%.

- The presence of an elevator, or an accessible ramp on out-of-the-way pedestrian crossings - 39,5\%.

- The presence of a countdown timer on regulated objects equipped with pedestrian traffic lights $-10,1 \%$.

II For persons with visual impairment:

- The presence of a sound device for pedestrians on regulated objects equipped with pedestrian traffic lights $-56,2 \%$.

- The presence of tactile tiles on pedestrian crossings and bus stops $-43,8 \%$.

For the accessibility of the SP were established indicators and their significance for each category of LMP.

I For people with musculoskeletal disorders (including wheelchairs users):

- The presence of the ramps at the entrance/exit and an acceptable height for landing in transport $-85,9 \%$.

- The presence of the space for placing a wheelchair - 14,4\%.

II For persons with visual impairment:

- The presence of tactile tiles.

To evaluate comfortability trip parameters were established for each category of LMP and their determined their importance.

For people with musculoskeletal disorders (including wheelchairs users):

- Presence and operation of wheelchair anchorages and the driver's communication button at the available level $(0,9-1,2 \mathrm{~m})-16,1 \%$.

- Closely drive to the bus stop' platform $-45,2 \%$.

- Driver's assistance at boarding in rolling stock $-33,4 \%$.

- Existence and serviceability sound and visual system of informing on a bus stop $5,3 \%$.

II For persons with visual impairment:

- Presence and serviceability of the sound information system about bus stop- 58,1\%.

- The comfortable location of seats-17,4\%.

- Presence and convenience of handrails contrasting colors $-24,5 \%$.

III For people with hearing loss:

- Presence and serviceability electronic scoreboard with the name of bus stop- $62,5 \%$.

- The comfortable location of seats $-37,5 \%$.

For the evaluation of information service options have been established for each category of LMP and determined their importance.

I For people with musculoskeletal disorders (including wheelchairs users):

- The availability of information on the Internet about the availability of bus stop for people with musculoskeletal disorders-33,4\%.

- Schedule availability information of routes for low-floor rolling stock at bus stops$46,3 \%$.

- The presence of visual and sound information about bus route number and its accessibility for people using wheelchairs (pictograms) $-20,3 \%$.

II For persons with visual impairment:

- The presence of information in the Internet on availability of bus stops for persons with visual impairment $-28,6 \%$.

- The presence of schedule in Braille at bus stops-22,9\%.

- The presence of sound information about the route number of the approaching rolling stock $-48,5 \%$.

III For people with hearing loss: 
- The presence of schedule at bus stops $-32,2 \%$.

- The presence of visual information about the route number at the rolling stock $67,8 \%$.

\section{Conclusion}

The analysis of normative legal acts in the field of transport LMP shows that since the early 90 's was adopted many legal acts, standards and government programs, both at the federal level and at the level of Moscow, aimed at improvement of transport services for LMP. However, the data of sociological polls suggests that many transport infrastructure is still not accessible for LMP. In order to determine the effectiveness of the legislation adopted and the activities undertaken, it is necessary to develop an integrated methodology for assessing transport services for LMP. Existing methodology standards do not take into account the importance of quality parameters for individual categories of LMP. The identification of the accessibility and quality of transport services for LMP, as well as the determination of their relevance, can be carried out through sociological surveys. The indicators of the quality level of transport service will assess the effectiveness of legal acts and activities aimed at improving services for LMP.

\section{References}

1. Federal'nyj zakon ot 24.11.1995 N 181-FZ "O social'noj zashhite invalidov v Rossijskoj Federacii» . Available at: www.consultant.ru (accessed 6 august 2017).

2. Federal'nyj zakonot 1 dekabrja 2014 g. \# 419-FZ "O vnesenii izmenenij v otdel'nye zakonodatel'nye akty Rossijskoj Federacii po voprosam social'noj zashhity invalidov v svjazi s ratifikaciej Konvencii o pravah invalidov". Available at: www.consultant.ru (accessed 6 august 2017) .

3. Federal'nyjzakonot 08.11.2007 N 259-FZ

"Ustavavtomobil'nogotransportaigorodskogonazemnogojelektricheskogotransporta". Available at::www.consultant.ru (accessed 6 august 2017) .

4. Postanovlenie Pravitel'stva RF ot 01.12.2015 \# 1297 "Ob utverzhdenii gosudarstvennoj programmy Rossijskoj Federacii "Dostupnaja sreda" na 2011 - 2020 gody". Available at: www.consultant.ru (accessed 6 august 2017) .

5. Prikaz Ministerstva truda is ocial'noj zashhity RF ot 06 dekabrja 2012g. \#575 "Ob utverzhdenii primernoj programmy subekta RF po obespecheniju dostupnosti prioritetnyh obektov i uslug $\mathrm{v}$ prioritetnyh sferah zhiznedejatel'nosti invalidov i drugih malomobil'nyh grup pgrazhdan" Available at: www.consultant.ru (accessed 6 august 2017)

6. Rasporjazhenie Mintransa Rossiiot 31 janvarja 2017g. \# NA-19-R "Ob utverzhdenii social'nogo standarta transportnogo obsluzhivanija naselenija pri osushhestvlenii perevozok passazhirov i bagazha avtomobil'nym gorodskim nazemnym jelektricheskim transportom". Available at: www.consultant.ru (accessed 6 august 2017).

7. Prikaz Mintransa Rossiiot 1 dekabrja 2015 goda N 347 "Ob utverzhdenii Porjadka obespechenija uslovij dostupnosti dlja passazhirov iz chisla invalidov transportnyh sredstv avtomobil'nogo transporta i gorodskogo nazemnogo jelektricheskogo transporta, avtovokzalov, avtostanciji predostavljaemyh uslug, a takzhe okazanija im pri jetom neobhodimoj pomoshhi" Available at: www.consultant.ru (accessed 6 august 2017). 
8. Zakon g. Moskvyot 17 janvarja 2001 g. N 3 "Ob obespechenii besprepjatstvennogo dostupa invalidov k obektam social'noj, transportnoji inzhenernoj infrastruktur goroda Moskvy". Available at: www.consultant.ru (accessed 6 august 2017).

9. Postanovlenie Pravitel'stva Moskvy ot 16 marta 2010 g. N 219-PP "O merah po obespecheniju besprepjatstvennogo dostupa invalidov $\mathrm{i}$ inyh malomobil'nyh grazhdan k obektam social'noj, transportnoj i inzhenernoji nfrastruktur goroda Moskvy". Available at: www.consultant.ru (accessed 6 august 2017).

10. Postanovlenie Pravitel'stva Moskvy ot 06.08.2002 N 623-PP "Ob utverzhdenii Norm i pravil proektirovanija kompleksnogo blagoustrojstva na territorii goroda Moskvy MGSN 1.02-02" Available at: www.consultant.ru (accessed 6 august 2017).

11. GOST 51090-97. Sredstva obshhestvennogo passazhirskogo transporta. Obshhie tehnicheskie trebovanija dostupnosti i bezopasnosti dlja invalidov [State Standart 51090-97. Means of public passenger transport. General technical requirements of accessibility and safety for disabled people] (vveden $\mathrm{v}$ dejstvie postanovleniem Gosstandarta Rossiiot 16 sentjabrja 1997 g. N 307 .

12. M.A. Kudrjashov, A.V. Shatalova, Analiz normativno-pravovogo regulirovanija perevozok otdel'nyh grupp naselenija avtomobil'nym transportom. Gruzovik.no.9. (2017)

13. V.S. Gajdaev, Ocenka logisticheskoj sistemy transportnogo obespechenija malomobil'nyh grupp naselenija: dis. kand. jekon. nauk. Pp. 192. (2012)

14. Ju.A. Jertman, S.A. Jertman, O.N. Perepelkina, A.N. Logunova, V.N. Karnauhov.Ocenka dostupnosti marshrutov gorodskogo passazhirskogo transporta dlja malomobil'nyh grupp naselenija. 3. Pp. 254-257. (2014)

15. O.N. Perepelkina, S.A. Jertman, Ju.A. Jertman, Ocenka dostupnosti uslug obshhestvennogo passazhirskogo transporta dlja malomobil'nyh grupp naselenija.Pp.100-104. (2015).

16. K.Je. Safronov, S.M. Mochalin, Ocenka programmnyh meroprijatij po povysheniju dostupnosti gorodskoj transportnoj sistemy dlja malomobil'nyh grupp naselenija. 4. Pp.30-38. (2015).

17. K. Je. Safonov, S. M. Molchalin, Obespechenie dostupnosti razlichnyh vidov passazhirskogo transporta dlja invalidov. Pp.45-52. (2015).

18. A. V. Shabanov, Regional'nye logisticheskie sistemy obshhestvennogo transporta: metodologija formirovanija i mehanizm upravlenija. Pp. 205. (2001). 